
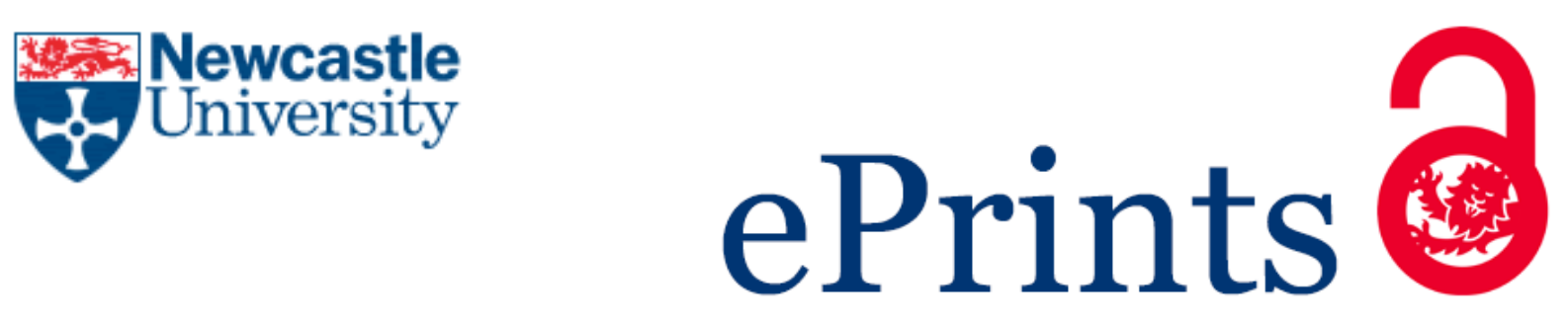

Zhu J, Morgan G.

Global supply chains, institutional constraints and firm level adaptations: A comparative study of Chinese service outsourcing firms. Human Relations 2017

DOI: https://doi.org/10.1177/0018726717713830

\title{
Copyright:
}

Zhu J, Morgan G. Global supply chains, institutional constraints and firm level adaptations: A comparative study of Chinese service outsourcing firms. Human Relations 2017. Copyright (C 2017 The Authors. Reprinted by permission of SAGE Publications.

DOI link to article:

https://doi.org/10.1177/0018726717713830

Date deposited:

$05 / 10 / 2017$

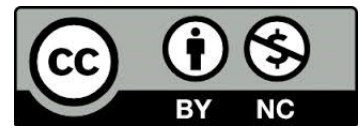

This work is licensed under a Creative Commons Attribution-NonCommercial 3.0 Unported License 


\section{Global supply chains, institutional constraints and firm level adaptation: a comparative study of Chinese service outsourcing firms}

\section{Introduction}

Despite the rich literature on global supply chains, there is limited understanding about how they relate to social relations at work. This is, to a large extent, due to the fact that global supply chain analysis itself tends to focus mainly on the governance of inter-firm relations in the chain, whilst paying less attention to the implications of these linkages for the internal structure of work and employment relations inside the affected firms (Smith et al. 2002; Coe et al. 2008; Taylor 2010). This has led to calls for studies which investigate how the internal dynamics of workplaces are embedded within the wider contexts of global supply chains (Taylor et al. 2015).

Four key themes have emerged in this development. Firstly there has been more focus on the strategic choices made by supplier firms which affect how they relate both to buyers and to issues of internal organization (Lakhani et al. 2013; Coe \& Yeung 2015). Secondly there has been recognition that institutional contexts shape the range of strategic choices available to managers in different contexts about how they engage with global supply chains (e.g. Lane 2008; Frenkel 2001).Thirdly, the variable influence of lead buyer firms on workplace relations in supplier firms has been identified (e.g. Barrientos \& Kritzinger 2004; Ngai \& Smith 2007; Raworth \& Kidder 2009). Fourthly there has been a greater appreciation of the ways in which the actions and capabilities of labour impacts on the organization of global supply chains (Newsome et al. 2015; Howcroft \& Taylor 2013; Cumbers et al. 2008). These themes reflect a renewed interest in the intersection between global supply chain analysis and institutional approaches (see the earlier debate between Whitley (1996) and Gereffi (1996)). Since this discussion - in which both sides agreed that there was potential 
complementarity between the two perspectives - there has been relatively little explicit dialogue (with the exception of Lane 2008 and Lane \& Probert 2009). In this article, we analyse how actors engage strategically with the opportunities and constraints arising from both surrounding institutional contexts and global supply chains. In doing so, we offer some concrete suggestions for how global supply chain analysis and institutional approaches can be fruitfully integrated.

This conceptual contribution is elaborated by way of an in-depth, comparative case analysis of two Chinese supplier firms providing outsourced services to Japanese companies. It draws on rich observational data, 140 interviews and archival materials at the supplier firms' workplaces in both China and Japan. We argue that the work and employment relations in the supplier firms are shaped by (a) being in a global supply chain where the lead firm makes certain demands on the supplier not just about the price, quantity and quality of outputs but also about inputs in terms of processes and practices and (b) being located in specific institutional contexts which provide particular sorts of resources for managers that shape how the firm can participate in particular global supply chains. The combination of these pressures from the global supply chains and the local institutional environments create potential gaps between what is required and expected by the lead firms and what is feasible within the supplier firms given the resources and constraints in their local institutional environments. In our conclusion, we suggest that there are a range of approaches which supplier firms may take to harnessing their institutional resources into global supply chains and bridging any gaps between their contexts and the expectations of lead firms. Our article, therefore, builds on those authors (e.g. Lakhani et al. 2013; Coe \& Yeung 2015) who look for ways to link institutional analysis and the global supply chains approach closer together but advances this literature by looking into the tensions and gaps created by the intersection 
between global supply chains, the expectations of lead firms and institutional contexts. Supplier firms make strategic choices about how to deal with these tensions.

\section{Firms, work organization and global supply chains}

Coe et al (2008) argue that global supply chain approaches tend to treat the firm as a 'black box' and focus mainly on understanding the linkages between firms and how they are governed using either a modified form of transaction cost analysis (the global value chain approach as in Gereffi et al. 2005) or an analysis of power differences between firms arising from market position and/or political influence (the global production networks approach as in Henderson et al. 2002). By contrast, we follow those researchers who remain open to what is influencing and shaping social relations at work in this box and in doing so use the terminology of global supply chains. In particular we draw on those scholars who have emphasized that firms in global supply chains have the capability to make strategic choices in how they organize their work systems (Coe \& Yeung 2015; Lakhani et al. 2013). These scholars reject the assumption that firms occupying similar positions in supply chains will respond in a similar fashion in terms of how they organize their work and employment systems and their labour process (Coe et al. 2008). They argue that this assumption is problematic because it treats workplaces as a 'dependent variable that absorbs the constraints stemming from particular forms of governance' (Hammer \& Riisgaard 2015: 86) and consistently downplays the agentic power of employers and employees in the chain (Bair \& Werner 2015) rather than allowing for the possibility of actors in the same global supply chains exercising 'multiple....types of firm-level strategy' (Coe \& Yeung 2015: 126).

Where does this possibility of variation arise from? Increasingly, researchers have recognised that this is related to local institutional contexts which to varying degrees shape the sorts of options for management and labour in different forms of capitalism (Hall \& 
Soskice 2001; Whitley 2007). As more recent institutional analysis has emphasized, institutional environments enable as well as constrain firms, leaving scope for strategic choice (Berger 2005; Kristensen \& Morgan 2012). In relation to global supply chains, it is the institutional embeddedness of labour that is most relevant to the shaping of the strategic choices which are available to managers, e.g. the wages, work conditions and skill levels of labour and the degree to which these are shaped by the collective organization or labour market power of workers in trade unions and the role of the state in regulating the workplace and managing labour supply through the development of training and educational institutions (Cumbers et al. 2008; Haidinger \& Flecker 2015; Appelbaum 2008; Smith 2006).

Much of the study of global supply chains has tended to focus on the low-value end of production systems which draw on large pools of relatively unskilled and undifferentiated labour who are employed in poor working conditions, subject to increasing casualization of employment and close surveillance in the workplace (e.g. Barrientos \& Kritzinger 2004; Morris et al. 2009; Wilkinson et al. 2001; Raworth \& Kidder 2009; Chan et al. 2013). In these contexts, institutions that strengthen the role of labour collectively or individually are weak. Although these studies provide valuable insights on how workers are organized and managed at the low-value end of global supply chains, they tend to treat workers as passive 'victims' reflecting and reproducing a 'labour as object' approach (Bair \& Werner 2015; Taylor 2015). These studies therefore underestimate the power of labour particularly in institutional contexts that may be characterised by a more highly skilled labour force (e.g. IT Business Process Outsourcing as discussed in Feuerstein (2013)), or where demand for labour is greater than supply and thus employees have some individual bargaining power which they can exercise by moving firms. These circumstances necessitate that firms take measures to hold on to valuable employees in order to participate in global supply chains.

However, managers' room for manoeuvre in their internal organization is also 
constrained by the expectations of lead firms about how work should be organized in their suppliers. Lead firms may demand that their suppliers in different countries match their own rather than their locally developed standards and practices. They may monitor and control what is going on in sub-contractors; they may transfer technologies and processes to subcontractors to ensure certain standards of output. Some buyers may take little interest in this as they treat their suppliers as inter-changeable providers of relatively standardised products (labelled 'market governance' in the typology generated by Gereffi et al. 2005). They therefore invest little in the relationship as it is short-term and requires little in the way of specialized assets. Their focus is on the output and whether it meets market requirements in terms of price and quality. Other buyers may require more customized outputs that need more interchange of information and people between themselves and the supplier. These buyers may seek a longer term relationship with an expectation of more control and input over work processes - what Gereffi et al. (2005) describe as 'relational governance'. 'Relational governance' may slide into 'captive governance' where the supplier becomes entirely dependent on one buyer and this buyer in effect dictates the internal work organization structure of the supplier. Such preferences on the part of lead firms also reflect an institutional dimension; for example, US firms are much more likely to be used to operating in market based supply chains than Japanese firms which are likely to be more embedded in firm networks and relational governance structures (Sako 1992; Sako 2006)

Therefore, in order to develop a more comprehensive understanding of the organisational consequences of global supply chains, one needs to understand how different types of global supply chain relations and governance arrangements are managed at the workplaces of supplier firms where local labour market conditions and local institutional contexts are central constraints on the imposition by lead firms of particular processes and practices. As Lakhani et al. (2013) state 'lead firm and national institutional influences on 
supplier employment relations, represent dimensions of employment systems that are unique to connected firms' (p.451).

Taking this a step further, however, we argue that managing the relationship between lead firms and the contingencies of the local context also requires a focus on how local managers in supplier firms mind the gap, that is, the gap between what is practical and feasible locally and what are the expectations of the lead firm in the global supply chain. Institutional constraints may make it impossible to organize in accordance with the requirements and expectations of lead firms while maintaining profitability. Therefore some impression management may have to take place to convince the buyers that their expectations are being met when in actual fact the supplier is having to adjust to local institutional conditions in ways which do not fit these expectations. This gives rise to our research question: how do supplier firms adapt to their local institutional conditions whilst meeting the expectations of their clients?

Our empirical cases show three main forms of adaptation in supplier firms. Firstly they may incorporate wholesale the expectations of the lead firm no matter whether this fits their institutional environment or not. If it does not, then they may need to find ways to insulate their work and employment system from the effects of the local context. Secondly, supplier firms may engage in ceremonial conformity, making it appear to the lead firm that they have adopted their practices whilst in reality running their organization in ways which conform to the local institutional context. Finally they may make minimal adaptations to their work system because the lead firm is primarily interested in output numbers and price and has little concern about how the supplier reaches these results - just that they do. In our conclusion, we argue that by focusing on the gap between expectations of the lead firm in the supply chain and the reality of what can be achieved in particular institutional contexts and utilizing this framework, we can bring together the supply chain approach and institutional 
analysis and open up the possibility of studying systematically the range of forms of adaptation that occur in supplier firms across a variety of sectors, value chains and contexts.

\section{Methodology and cases}

In order to explore these interactions between global supply chains, institutional conditions and the management of the work organization inside supplier firms, we investigated two supplier firms operating in global supply chains for IT services. IT services were chosen because they are considered as highly internationalised functions in offshore outsourcing, but beyond the example of India tend to receive less attention than the manufacturing sector in research on global supply chains (Flecker \& Meil 2010). In our cases, the suppliers are Chinese firms and the buyers are Japanese firms. The services supply chain between Japan and China constitutes an empirical setting which is largely unexplored, surprising given that Japan was one of the earliest clients of China's BPO firms and remains the second most used destination for Japanese IT outsourcing following India.

The two Chinese firms share similarities in the sense that both are parts of IT services supply chains and both have been closely involved for two decades in providing outsourced IT services to Japanese companies both offshore (in China) and onshore (in Japan). However, the institutional contexts in which they are embedded differ due to the variegated nature and regionalism of Chinese capitalism (see Breznitz \& Murphree 2011; Zhang \& Peck 2016). One of the firms, Data-Co (anonymised for reasons of confidentiality), is private, whilst the other, Software-Co (similarly anonymised), was established, funded and managerially controlled by a public university, thus constituting a particular kind of state-owned enterprise (see Eun et al. (2006) for a discussion of Chinese university-run enterprises). Data-Co is based in Dalian City in North East China whilst Software-Co was established and remains based in Shanghai.

The empirical case studies were developed from 2011 in four research sites in both 
China and Japan: the Chinese workplace of Data-Co in Shanghai, the Japanese workplace of Data-Co in Tokyo, the Chinese workplace of Software-Co in Dalian and the Japanese workplace of Software-Co in Tokyo. Researching both Chinese workplaces and Japanese workplaces allowed us to capture the cross-national nature of these firms. The focus of empirical study was on how lead firms and institutional environments affect supplier firms and how the management of supplier firms develop their work and employment systems to manage these influences.

Multiple research collection methods were adopted including observation, interviews and archival materials. The observation involved the first author working as a full-time, yet unpaid HR consultant within Data-Co's Chinese workplace for two months and then in both firms' Japanese workplaces in Tokyo for another two months. Observations in Japan primarily took place in the supplier firms' Japanese subsidiaries which served as the intermediate offices between Japanese clients and Chinese workplaces. In these subsidiaries, it was possible to observe how subsidiary managers and employees interacted with a range of different Japanese clients and how they communicated with the Chinese workplaces. These observations thus provided great insights into the requirements of multiple clients, as well as the dynamics between the supplier firms and their multiple Japanese clients. Visits were also paid to one Japanese client's site of Data-Co and three work sites of Software-Co's major client, which offered direct details of the working environments in Japan. Participant observation was not permitted in Software-Co's Shanghai workplace by the management. However, one HR associate was 'shadowed' for two half-days in Shanghai and also some time was spent in the Shanghai operating rooms observing how programmers and developers worked in teams.

The observations included active participation in the company's various events, close observations on events happening around the researcher, large numbers of informal 
conversations with different employees, and detailed field notes recording observations, participation and thoughts. Such observations generated insights into the general working environments and employees' daily experience at work as well as outside work. The researcher also stayed in the employees' dormitory in Japan, so had opportunities to participate in the leisure activities of employees as well as observing their lives outside work. In the light of the researcher's position as a HR consultant working with the management teams of the supplier firms, the researcher followed Hammersley \& Atkinson's (1995) suggestions to stay reflexive in data collection and analysis by understanding informants' accounts and the contexts in which they were produced as well as understanding how the researcher's presence affected people's actions and behavior.

140 interviews were conducted during the primary fieldwork in 2011 and 2012, and the follow-up period in 2013 and 2014. Table 1 breaks down the interviewees by research site. The variation in interview numbers at different workplaces is partly affected by the number of employees at each workplace but more fundamentally, they reflect the sample technique adopted in this study. The sampling here is informed by the notion of theoretical sampling, which is 'responsive to the data rather than established before the research begins' (Corbin \& Strauss 2008:144). As such, the numbers of interviews at different workplaces reflected the point of 'saturation', that is, when all research categories relevant to lead firm effects, institutional effects, management and employment systems in the supplier firms and the relations between these categories were well grounded in data, and at the same time new cases and analyses no longer provided new knowledge and insights. The entire interview dataset covered all positions in the organizational hierarchy in both firms. The length of the interviews varied from 60 to 90 minutes each. Most interviews were undertaken in the Chinese language except for seven which were in Japanese with the help of an interpreter who spoke both Chinese and Japanese. All interviews were recorded and subsequently 
transcribed with the exception of seven individuals who preferred not to be recorded.

Finally, analysis of archival materials provided macro-level data on the historical and institutional context of service outsourcing industry and the two case firms since the 1990s. Such deep case studies combining close observation and interviews in a cross-national context give rich and deep knowledge about what 'actually happens' and about 'how things work' at workplaces (Watson 2011:204).

Table 1: Interviewees by research site

\begin{tabular}{ccccc}
\hline Research sites & $\begin{array}{c}\text { Data-Co } \\
\text { (Dalian, China) }\end{array}$ & $\begin{array}{c}\text { Data-Co } \\
\text { (Tokyo, Japan) }\end{array}$ & $\begin{array}{c}\text { Software-Co } \\
\text { (Shanghai, China) }\end{array}$ & $\begin{array}{c}\text { Software-Co } \\
\text { (Tokyo, Japan) }\end{array}$ \\
\hline $\begin{array}{c}\text { No. of total } \\
\text { employees } \\
\begin{array}{c}\text { No. of } \\
\text { interviews }\end{array}\end{array}$ & $1000+$ & 55 & $850+$ & 122 \\
\hline
\end{tabular}

The analysis was undertaken in an iterative coding process, starting with picking out key events, issues and interactions from the interview transcriptions, field notes and archival materials from Data-Co and moving on to producing thematic categories, loosely informed by the literature on global supply chains and management control. Data was then analyzed from Software-Co and compared with the codes generated through the analysis of Data-Co's data. The events, issues and interactions in Software-Co were grouped into the existing codes when they fitted. At the same time, these codes were added to or amended to incorporate additional instances. During this process, data from Data-Co was examined again: when new codes emerged, previously coded data were recorded to see if they contained any examples of the new codes. In this sense, the process of coding was a recursive one.

The analysis of the empirical data is presented in the following section, first for DataCo and then Software-Co. We first discuss the global supply chain context of the Chinese firms and then analyze the influence and expectations of the Japanese lead firms, following this by sections on employment practices and work systems, operational systems and finally 
the gap between the expectations of the lead firm and how the supplier actually organized its workplace.

\section{Data-Co}

Data-Co initially entered into the BPO supply chain based on the founder's personal networks with a small number of Japanese firms. It aimed to maintain long-term relations with these firms by offering customized services and hoped to further develop new clients through existing clients' recommendations. However, in the early 2000s, Data-Co reviewed its strategies and decided to change its supply chain strategy from 'building up long-term, personal-based relations with a limited number of clients' (D-D2), to establishing contractual relations with as many clients as possible. Data-Co offers standardized instead of customized services and ends up taking many one-off orders from different clients. To survive in this product market, it needs to be highly cost efficient, highly accurate, highly data security conscious, highly flexible (to changing amounts of business between busy and quiet seasons) and, overall, highly sensitive to the expectations of Japanese buyers.

This market based strategy was facilitated for Data-Co by its local institutional environment in Dalian. Dalian City is a port city in Liaoning province and is the major gateway to China's northeast region. Being less than two hours away from Japan by airplane and a former colonial city of Japan, the Dalian local government has taken a distinct development path since the 1990s, largely relying on providing relatively low-skilled outsourcing services to Japanese organisations. This strategy has led to a booming business cluster of hundreds of companies providing business process outsourcing (BPO) and information technology outsourcing (ITO) services. In Thomas Friedman's (2005) bestseller 'The World is Flat', Dalian City is described as the 'Bangalore of China'. This regional strategy has been reinforced with the growth in Dalian of a large population of low-skilled 
migrant workers from the rural areas of Northern China. These migrants have been able to study in the local Dalian technical schools for one or two years and then seek job opportunities in the cluster. There are more than 15 technical schools in and near Dalian City, which provides a large pool of job candidates every year. According to Simeon (2010) quoting the Xinhua news agency, about 40,000 students in Dalian were learning software technologies in 2007 and half of these students were also learning Japanese as preparation for working in outsourcing activities with Japan. Dalian therefore is characterized by large numbers of firms offering outsourcing services to Japanese companies; these companies have a large pool of potential employees with technical school level training to draw on. As the general manager reflected, the local institutional environments in Dalian largely shaped the firm's focus on providing low-skilled services of data inputting and editing:

Of course, we thought of providing services that were high skilled...like dealing with software, system solutions...But the recruitment approach would be very different. We are trying but it requires time and money...perhaps as our long-term vision...our current services and strategies make the best use of the local resources. We are supported by the local government and we create jobs for the local cluster (D-D38).

\section{The influence and expectations of the Japanese lead firms}

In Data-Co, there is a high level of seasonal fluctuation in demand for its services as it specializes in inputting data for the annual reports of Japanese companies and editing Christmas and New Year cards. Every year, the period from August to the following February is considered to be the 'busy season'. By contrast, March to July is seen as the 'low season', during which the firm and consequently the workers do not get as much work to do. Managers agreed that to keep the company running, they needed four to five big orders (requiring more than 500 workers) for the 'busy seasons' and a dozen small orders (requiring 
fewer than 100 workers) for the 'low seasons'. The BPO managers said the company had three to four relatively stable clients from which they received large orders for the busy seasons every year or two years. Even so, they stressed that these clients 'could not be taken for granted' and the company still needed to work hard to win these business in the bid every time (D-D14).

Despite the great diversity of clients, it was evident that the Japanese lead firms' requirements for BPO work were similar. First, in relation to the products, lead firms sign a standard Service Level Agreements (SLA) with Data-Co, in which they specify four main product parameters, including the exact quantities of products to be delivered by Data-Co, the date of delivery, the price, and the quality (as measured by the delivery accuracy rate which is set at $100 \%$ ). The SLA also details the penalties if Data-Co fails to meet any of these parameters. Second, Japanese clients require their BPO suppliers to develop an information security system to ensure the safety and confidentiality of input data. However, informants across different projects serving different clients made the consistent comment that Japanese lead firms did not engage in detailed monitoring that all these procedures and practices were in place and working effectively. The main concern of Japanese lead firms is in terms of output accuracy and less on the detail of how this is achieved. This was confirmed by one Japanese advisor, who used to be Data-Co's big client and was hired by Data-Co as a senior advisor after his retirement from the Japanese firm. He said that for the kind of BPO services provided by Data-Co, Japanese firms had minimal involvement in daily operation - 'we compared and evaluated carefully during the bidding process. Once contracted, we let them [the suppliers] do their work. What we care most is whether they deliver the quality we expect on time' (D-T6).

Despite the Japanese firms' minimal daily involvement, the Chinese management cannot entirely ignore the Japanese clients' expectations; they have to look as though they are 
conforming or at least not flouting them. This is of particular importance on two occasions. First, during the bid process, Japanese lead firms undertake comprehensive evaluations of the potential suppliers based on their bidding materials. According to our informants, Japanese lead firms assess the suppliers' qualifications, the efficiency of their workplace procedures and the skill levels of their workers. They also check the past performance of each potential supplier in terms of their accuracy rate and delivery time, and talk to their previous clients. Therefore, supplier firms are pressurized in market competition to develop work procedures that meet Japanese clients' expectations and demonstrate their capabilities to deliver quality services. Second, many Japanese clients pay visits to the suppliers' Chinese workplaces before they make the final decisions. During the visits, Japanese clients observe the workplace, check workplace routines and examine the daily practices. Managers in Data-Co considered these visits as great opportunities for them to impress the Japanese clients; as one manager reflected:

[During the visits], we need to show that our procedures are standardised, our management is advanced and our workers are skilful - all meets their [the Japanese firms'] expectations, if not beyond. (Field note in Dalian)

It is worth reflecting that even though both sides saw this as a market based contract, the Japanese clients still went through some of the motions of 'relational contracting' in ways that would not have been the case, for example, for US companies; in other words the Japanese lead firms were conforming to a limited extent to the Japanese model of building a relationship (through the visits and the checks) and the Chinese managers understood they had to play this game, showing a familiarity with Japanese standards and expectations. They could not treat the Japanese clients as 'clients' in an abstract, non-specific way; they had to treat them as Japanese and recognise that this meant highlighting certain aspects of their own practices which accorded to their understanding of what Japanese firms expected. 
Employment practices: recruitment, training, pay, performance management and retention

Given the seasonal nature of its business, Data-Co's first problem is matching the quality and quantity of its labour force to the predictable peaks and troughs of its business. Data-Co wants its labour to be both available (in the busy seasons) and disposable (in the quiet seasons).

In terms of quality, Data-Co requires technical school graduates with competence in basic computer skills. It achieves this through recruiting senior graduating students from local technical schools, with which it has developed close collaborations. The recruitment (accompanied by a 3 month training period) takes place every year and it is strategically scheduled before the busy season every year, so that there is enough 'hoarded' labour for the incoming business. New student recruits have to finish a one-year internship assignment before they can sign a standard three-year employment contract with the company. These interns are paid at a much lower wage rate (at 400-600RMB per month) than that of the established workers and the mid-career entrants (normally at 1,100-3,000RMB per month). The use of student interns in this way has become common in China (Smith \& Chan 2015)

Second, Data-Co manages to achieve a certain level of labour flexibility and cost efficiency by 'letting' workers voluntarily leave for other companies during the low season, without making much effort to retain them. This is achieved by implementing a pay system which minimises the fixed basic pay whilst emphasizing variable piece-rate bonus. On the one hand, the fixed basic pay only accounted for $40 \%$ of employee monthly income (corporate report, 2013). The fixed basic pay in Data-Co (avg. 800RMB) was clearly inferior to the best rates in the Dalian BPO cluster (avg.1000RMB). On the other hand, workers got well paid during the busy seasons when they had lots of overtime opportunities. During the quiet season, however, when workers are not doing overtime, pay is particularly low, leading 
to people leaving the company at that time - which in turn reduces costs to the firm. One informant reflected, "we stay during the busy seasons and we are free to job-hop during the low seasons to secure a higher basic pay’ (D-D12).

Notably, even the so-called 'fixed' basic pay is not stable and guaranteed. This is because workers are required to take a skill exam every June, regardless of their length of service, and the exam results will decide their basic salaries for the upcoming year, in a distribution determined by management (Table 2). The results ensure overall stability in the wage bill, which is important in terms of pricing contracts in highly competitive markets. For employees, however, the result is uncertainty about their future earnings as they can drop grades for a variety of reasons, not just individual performance but also as a consequence of the overall changes in the abilities of the ever-changing cohort and the individual's ranking within that. This uncertainty about future earnings results in employees 'voluntarily' leaving the firm both because they are dissatisfied with their upcoming basic salaries and with their inability to secure a particular grade (and associated wage) over longer than one year at a time.

Table 2: Distribution of scores and basic salaries in Data-Co

\begin{tabular}{llllll}
\hline Score & $0-50$ & $51-70$ & $71-90$ & $91-100$ & above 100 \\
\hline Grade & grade 1 & grade 2 & grade 3 & grade 4 & grade 5 \\
$\begin{array}{l}\text { Basic salary } \\
\text { (in RMB) }\end{array}$ & $600-699$ & $700-799$ & $800-899$ & $900-999$ & $1000-1100$ \\
$\%$ of employees & $5 \%$ & $50 \%$ & $25 \%$ & $15 \%$ & $5 \%$ \\
\hline
\end{tabular}

Source: Interviews and corporate documents.

Third, maintaining labour flexibility in this way was facilitated by a well-established and short-term training system, through which the inexperienced recruits are trained to be qualified semi-skilled workers within three months. Data-Co's training programme exclusively focuses on the basic skills of typing Japanese characters, letters and numbers. Interns are taught to use an application, which enables them to type Japanese characters based on their structures (appearances), rather than on pronunciations or meanings. In this way 
managers demonstrate that 'the company is able to train workers within three months to become semi-skilled workers, even if they know neither Japanese nor about computers before they join' (D-D10).

These strategies using the local institutions of the labour market and the local training system have enabled Data-Co to manage employees in a low cost and flexible way that fits well in a market-based supply chain featuring fluctuating client demand and high sensitivity on cost. However, this does not mean the firm does not need to worry about employee retention. In an industrial cluster where hundreds of similar companies congregate with no restraints on labour 'poaching', and in an employment system that is largely based on nonregular employment and has no shortage of vacancies for those willing to work under such circumstances, the mobility power of employees is strengthened, especially amongst experienced workers. Employees have used their mobility power informally (i.e. with no support from their party controlled trade union) but collectively by threatening to leave just before the busy season arrives and forcing employers to concede improved conditions. One year, for example, management announced an extra subsidy of 150RMB to settle a potential mass resignation before the busy season. However, employees did this only rarely in part because management did not always make concessions and in part because most workers were reluctant to exercise their power (and potentially leave) at the point when they were about to earn their highest rewards.

\section{Operational system and workplace}

To achieve the $100 \%$ delivery accuracy required by the lead firm in the SLA, Data-Co develops a work procedure which is called the 'double input and multiple checks' system. Under this procedure, every piece of work needs to be input twice by two separate operators, followed by a three-fold checking process including a comparison check between the two 
inputs (by team leaders), a sample check (also by team leaders) and a final check before delivery (by project managers). Mistakes identified during the comparison check and the sample check will be corrected immediately. Failure to be accurate will be logged on the individual's performance chart. If there is any problem identified during the final check, workers are likely to be asked to re-do the whole task.

There is no independent and separate monitoring of accuracy by the lead firm. One manager explained that delivery accuracy is measured loosely on the feedback from clients after delivery; 'as long as the clients do not identify any mistake after delivery, we assume that the delivery accuracy for this project is $100 \%$ ' (D-T3). While this work procedure does guarantee as high a level of delivery accuracy as Japanese clients expect, it is a labour intensive approach, which relies heavily on the low cost of labour in China and is largely based on repetitive checking and rectification. This is in sharp contrast with the 'Japanese' ways of quality management, in which quality is 'built in' to the production and guaranteed by a skilled workforce (Hill \& Wilkinson 1995). Nevertheless, this work procedure reflects Data-Co's choice to mobilize local institutional resources and adopt a strategy which is only possible in a low wage economy with plentiful amounts of workers. It is an example of the way in which the expectations of the lead firms are met but not in the ways expected - it is achieved due to the specific institutional context of the supplier firm.

Another expectation of many Japanese lead firms was that the Chinese supplier would be ' $5 \mathrm{~S}$ ' compliant. $5 \mathrm{~S}$ is a Japanese developed visual control system which aims to contribute to cost-effectiveness by ensuring seiri (tidiness), seiton (orderliness), seiso (cleanliness), seiketsu (standardisation) and shitsuke (discipline) of the workplaces (Liker, 2004). Based on this system, workers are required to comply with eleven rules concerning the tidiness and cleanness of the workplace. Data-Co had met this expectation and implemented 5S. There were posters of ' $5 \mathrm{~S}$ Rules' hanging on the walls in each operating room. There was also a 
warning scheme named 'Yellow, Red and Black Card' under which yellow, red and black cards were given respectively to employees who broke the rules once, twice and three times. Anyone who got a black card would be financially punished. Managers explained that although not all Japanese clients explicitly required the 5S system, it was adopted and implemented in all projects to 'impress' the Japanese firms, particularly during their visits to the workplace. One manager commented:

When Japanese clients visit us, we want to give them the feeling that they are visiting a Japanese company -- nothing other than a Japanese company located in Dalian, China...5S is a common practice in Japanese organisations and they [Japanese managers] will be pleased to find that we are imitating their practices and workplaces.

In practice, employees felt themselves coerced into following these rules and wondered what benefit they could get from this system. In interviews and informal discussions, many employees described these rules as 'ridiculous' and 'trivial'. Several employees, including some skilled team leaders, quit their jobs due to the sanctions imposed on them for failing to achieve 5S standards. In fact, observation revealed that these rules were not implemented and monitored on a daily basis. This was confirmed by two team leaders who suggested that $5 \mathrm{~S}$ rules were only carried out when Japanese clients paid visits to workplaces. They reported that managers would inform them in advance when clients were visiting so that they had enough time to organize the workplaces as required by the $5 \mathrm{~S}$ rules (D-D22, D-D16). This further underlines that whilst the Chinese firm sought to meet the lead firms' requirements, the way in which this occurred was patchy and with far less commitment than in Japan. There were fewer supports for $5 \mathrm{~S}$ in the Chinese institutional context than in Japanese companies where it is deeply embedded. However managers and employees recognised that its main usefulness was in impressing Japanese clients on their occasional visits, even if detailed 
monitoring of $5 \mathrm{~S}$ was not given much priority at other times. It was not fully accepted by employees and managers did not see the point of implementing it stringently given the risk of conflict with the workforce.

A similar pattern is found in the implementation of the information security system. All BPO firms in Dalian that serve Japanese organisations are required to develop an information security rules system that follows the Japanese standard of Personal Information Protection Assessment (PIPA). Data-Co's managers talked a lot about how they 'set up rules as requirement in PIPA' and 'update these rules when a new potential danger is identified'. They reported that they now had hundreds of rules under 23 categories. However, none of them mentioned how these hundreds of rules were carried out in practice. When pressed about the implementation, they did not deny that there were lots of rules which were not fully carried out. They explained that the rules were set up for inspection by clients, i.e. to meet the requirements of the Japanese lead firm so that when representatives of that firm were on site in China they could be shown the supplier was conforming to their expectations. In reality, however, managers allowed a system where workers could carry them out flexibly in order not to reduce productivity.

\section{Managing the gap between lead firm expectations and supplier firm realities}

How does Data-Co maintain legitimacy with its Japanese clients even if its implementation of required practices is only ceremonial? The fieldwork clearly revealed that Japanese clients concerned themselves with whether the suppliers had covered all the details and rules existing in the paperwork and paid relatively little attention to how these rules were carried out in practice. One informant reflected:

During the visits, they [Japanese clients] walk around the building and take a look at our operating rooms. They do not normally ask to enter into the operating rooms. 
They just have a look through the windows. Frankly, the observations through these visits are superficial. They do sometimes ask us how certain rules are carried out orally, but they do not check in practice. (D-T12)

In summary, in order to provide standardised, highly accurate products that are required in a market-based supply chain, Data-Co has developed a management system which mobilizes the local resources available and fits well with the local institutions. This system has centred on the use of low-skill, low-cost student employees, flexing employment levels to business fluctuations and the adoption of a labour-intensive work procedure to ensure $100 \%$ accuracy. It has in effect made use of the institutional context to meet the output requirements of the supply chains. But it has not achieved this by copying Japanese work practices, which would have required Chinese managers and employees to fundamentally change their ways of working. Nevertheless, they could not simply ignore these Japanese work practices. Instead, Chinese managers engaged in a ceremonial adaptation to what they perceived as important practices that the Japanese clients would expect to see in place. They made sure that conformity to Japanese practices such as 5S and PIPA was visible and convincing when Japanese clients were visiting but weakly enforced when they were not on site (which was most of the time). Japanese lead firms did not invest in more detailed levels of monitoring and checking what went on inside their Chinese supplier so long as their output was on time and at the required quality and quantity level. Their limited and superficial evaluations allowed Data-Co to only loosely couple the formal rules with the actual daily work activities whilst giving the impression of conforming to the lead firm's requirements.

\section{Software-Co}

Software-Co was established in 1991 as an offshoot of a major Chinese university based in Shanghai. It only started receiving business orders (and generating revenues) from Japanese 
firms in 1996 and did not fully engage in the outsourcing business until 2001. Between 1991 and 2001, Software-Co primarily focused on running a training programme in collaboration with the Japan International Development Organisation (JAIDO). In this programme, selected Chinese university graduates were sent to Japanese firms for a minimum of three years and received on-the-job training (OJT) in the fields of software design, development and programming. The initiative of this training programme was seen by the University as 'a response to the Chinese State's call for developing high-tech industry and high-skilled talents' (S-T1). The training program was partly funded by the State through the university and partly funded by JAIDO. Between 1991 and 2001, about 120 trainees finished their training in Japan and went back to work in the Chinese workplace at Software-Co as software developers. These well-trained software developers spoke both Japanese and Chinese and had experience in working in Japanese firms. In 2001, JAIDO exited from the collaboration, which led to the end of the training programme. From this point, Software-Co instead became a full contractor of software services for Japanese companies.

Unlike Data-Co, Software-Co strategically positions itself in the relatively high-value end of the IT services global supply chain, aiming to provide highly skilled and customized services to its Japanese client. Such a strategy is due to the well-trained developers accumulated in the training programme on the one hand, and on the other hand, reflects the human resources available in the local labour market. Software-Co is located in Shanghai, the commercial and financial centre of mainland China. As one of the biggest job markets in China, Shanghai has a large pool of not only semi-skilled workers, but also high-skilled talents. There are 67 universities in Shanghai, ten of them listed as listed as 'National Key Universities' of China and the top four of them belong to the '985 League' of Chinese universities, a Chinese equivalent to the US 'Ivy League'. International outsourcing service is a growing industry in Shanghai. In 2010, there were 822 service outsourcing companies in 
Shanghai. The value of signed service outsourcing contracts reached USD 2.753 billion, a year-on-year increase of $63.6 \%$ (KPMG 2013). Compared to the outsourcing service firms in

Dalian which heavily rely on technical school graduates, those in Shanghai enjoy access to talents at different levels of skills, including the most highly educated and skilled graduates in computing and software development. More problematically, Shanghai has the second highest level of labour cost in China, just behind Beijing (National Bureau of Statistics of China, 2015). This subjects firms to pressure in terms of labour recruitment and retention, especially of skilled workers.

\section{Influence and expectations of the Japanese lead firm}

Like Data-Co., Software-Co also started into the outsourcing business with a small number of Japanese clients. However, instead of developing high volumes of new clients as Data-Co does, Software-Co now devotes itself largely to one single client, from which it gets almost $90 \%$ of its total business. Since 2001 , Software-Co has gradually terminated contracts with other existing clients and stopped developing new clients. It has been concentrating on building a long-term relationship with the Nomura Research Institute (NRI), a well-known Japanese firm operating in the fields of consulting, financial IT solutions and IT platform services. Despite the risk of such high reliance on NRI, Software-Co's management agreed that the future of the firm lay in its capability to increase the mutual interdependence between the client and itself. As one manager explained, 'we want to be able to provide distinctive solutions to our clients so that our clients rely on us as much as we rely on them' (S-T2). To achieve this, Software-Co emphasized the importance of accumulating highly specialist knowledge of NRI and its procedures, practices, technologies and business strategies. It aimed in this way to become a co-producer of knowledge with NRI, creating a mutual interdependence not just a 'captive' relationship. 
This reflected the high level of influence which NRI expected in terms of SoftwareCo's internal processes. The Service Level Agreement sets out not only product parameters in terms of quality and cost, but also the procedure standards. NRI prescribes the exact work procedure to be followed by Software-Co, the particular programming language and platform to use and the precise numbers of employees engaged. The requirements on customized software design and detailed procedural specifications require NRI to get deeply involved in Software-Co's daily operation and management. NRI needs to communicate with SoftwareCo employees to make sure they understand their requirements. It offers training to employees from Software-Co on the prescribed work procedures and systems, and monitors their implementation at workplaces. NRI requires Software-Co to have highly trained employees who are capable of meeting Japanese standards and communicating in detail with NRI's Japanese employees.

\section{Employment practices: recruitment, training, pay, performance management and retention}

In order to respond to this, Software-Co actually divides its activities into two interdependent tasks: software design and software programming. Software design is seen as the key highvalue service being provided to the lead firm. The aim is to provide a highly customized and therefore high-value service to clients. This requires detailed and continuous interaction with Japanese employees of the lead firm to determine the nature of the tasks, the problems to be solved, the viability of the solutions addressed in terms of the client's system architecture as a whole, all of which require the two firms to work very closely together and to develop high trust relations. Turning the software development into software programming, on the other hand, involves conducting monotonous coding and testing according to manuals to ensure high rates of accuracy. Accordingly, these subdivided tasks lead to two different employee groups: software design is conducted by software developers while programming is carried 
out by software programmers. Developers are considered as the core of the company while programmers are seen as the periphery workers who offer routinized work.

Employment practices for software developers and for programmers offer a sharp contrast. Software developers are selected from the top four universities in Shanghai. Once hired, developers are provided with a systematic training for a minimum of five years. This includes one year of off-the-job training at university in the Japanese language, one year of on-the-job training (OJT) at the Shanghai headquarters to learn the basic procedures and techniques involved in software programming and design, after which trainees are expatriated to Japan and given three years of OJT in Japanese clients' companies. By the end of this period, developers are highly knowledgeable about Japanese business practices, about NRI's processes and procedures and about software development. They are highly valuable employees in the context of Shanghai's outsourcing sector.

Unlike in Japan, where such high levels of investment in employees are common in return for a lifetime commitment to the firm and this is embedded in very low levels of midcareer mobility, in China, no such system has existed since the end of the regulated communist economy during the 1980s and the rise of deregulated labour markets (Friedman \& Lee 2010). Instead, the system has encouraged employees and employers to act opportunistically in the labour market where possible (Kuruvilla et al. 2011). In Shanghai and particularly in the high growth areas of software etc., moving around for the highest salary has become common and salaries have generally risen for this group of employees. Therefore, to ensure that in this institutional context it does not lose the major investment it has made in training the software developers, Software-Co has to resort to particular retention tactics that insulate its software developers from this local institutional context. For example, trainees have to sign a legal agreement with the company before they leave for Japan, agreeing to serve the company for at least five years after they complete their training in 
Japan. Those who fail to fulfil this commitment have to pay the company liquidated damages of $100,000 \mathrm{RMB}$. The lengthy training and the financial constraints after the training mean that once hired, these developers are locked into 10 -year contracts (5 years training and 5 years post-training with major financial penalties for early exit from the firm).

There is more than just economic lock-in at work as the training programme which they undergo in China and Japan instils in them a commitment to their collective identity as an elite within the company and in this sector of the industry more generally. During their training in Japan, for example, they live together and they work stressful long hours at the same Japanese workplaces. They share with each other their feelings of being away from home and the anxieties which this generates in terms of working and living not just in any foreign country but in Japan which has historically had difficult relations with China over a long period of time and particularly in the $20^{\text {th }}$ and early $21^{\text {st }}$ centuries. All of this pushes them to rely on each other in both work and life. They see each other as the best of colleagues, friends and even as family. They spend most of their time within their 'comfort zone' with each other, to the extent that they lose opportunities and motivation to socialize with other people. Many developers said it was the culture among developers that kept them in Software-Co and they valued this culture as 'distinctive', 'priceless' and 'irreplaceable':

I do not think you can find a similar culture in any other workplace. It is distinctive, neither Japanese nor Chinese, it is just 'Software-Co'... It comes from years of shared experience and strong sense of camaraderie...I truly believe that one who has adapted to and liked the Software-Co culture would find it extremely difficult to work for other work environments (S-T12).

In terms of pay, the salaries of these software developers are at the top of the market and they increase on an annual base. There also exists a structured internal career path through which developers pursue career progression. Combined, these employment practices constitute a 
working situation which is seen by many developers in Software-Co as being too good to leave. Indeed, company statistics show that between 2005 and 2010, no single developer quit after completing training. Software-Co can therefore invest in their elite developers because they have built barriers to their exit; they have insulated them from the local institutional context in order that the practices of the Japanese lead firm can be incorporated wholesale into the activities of this group.

By contrast, programmers are sourced from various channels including universities, local job centres, job agencies and personal recommendation. Campus recruiting is conducted every spring at colleges and universities all over China, and other sources are used whenever needed. Programmers are selected based on specific skills, experiences and qualifications in computer-related areas. No training is provided to them and they only work in the Chinese workplace. The absence of training poses challenges to the programmers, especially the newly-hired ones. One new programmer said that she had to learn the Japanese language in her spare time to use the operating system which is displayed completely in Japanese. Yet, she received no support from the company (S-S26). Programmers are paid a monthly salary which is also determined by their length of service. In contrast to the top level salary of developers, the salary rates for programmers are below the industrial average and many programmers are not satisfied with their earnings. Whilst developers have a clear career path based on internal promotion, programmers have few prospects for career advancement within the company since all managerial positions are taken by developers. Given this, many young programmers use Software-Co as a springboard for their careers, and expect to leave for another company as soon as they accumulate some experience. In effect, programmers are disposable labour, paid at a low rate to do standardized tasks and easily replaceable. Not surprisingly, average turnover rates among programmers were above $50 \%$ every year. For this group, then, Software-Co was happy to rely on local institutional resources. They were in 
effect insulated from the scrutiny and control of the Japanese lead firm which conducted all its business through the elite software developers.

In summary, investing and retaining core employees whilst flexing peripheral ones for the purpose of labour flexibility and cost reduction characterizes Software-Co's employment system. This system reflects Software-Co's strategy to combine the opportunity available from lead firms (i.e. the training), the talents available in the local labour market and accumulated over the past training programmes, and the readily available software programmers in the local labour market. This system also manages to retain core employees by creating an internal labour market based on high salary, high status, firm-specific training, structural career advance, and fines for early leaving.

\section{Operation system and workplace}

Given the high involvement of the lead firm in Software-Co's daily operation and the lead firm's specific requirements on work procedures and standards, one key element in SoftwareCo's work system is the immersive socialization into Japanese work practices and systems. Such socialization takes place in a systematic on-the-job training (OJT) program at the sites of the Japanese clients. On-the job training is a compulsory part of training for every developer in Software-Co. During the OJT, developers are trained and supervised by both Japanese clients and Software-Co's Japanese office. They are assigned to a team in the Japanese client firm. They are given tasks and allowed access to all information. Each developer is allocated to an experienced member of staff in the Japanese client who works as a coach and provides instructions to help them learn skills and processes. Under such arrangements, developers are considered as the learners and eventually carriers of 'Japanese' knowledge and practices back into Software-Co and its operations in China. They are provided sufficient time and opportunities to acquire and accumulate knowledge of Japanese 
management, to adopt Japanese practices in their daily work, and to update their experience and perceptions about Japanese management during their socialisation with Japanese colleagues and clients. This first-hand knowledge and experience of Japanese management builds a strong relationship and set of network ties between the Chinese supplier and the Japanese client leading to confidence in the ability of Software-Co to deliver to the levels expected by the Japanese firm.

Trained developers bring Japanese procedures and standards back to China and implement them in Chinese workplaces. Such procedures and standards included a suggestion system, which encourages developers to give constructive suggestions to improve the existing systems; a knowledge sharing program aimed to accumulate knowledge through developers' sharing and improving the capabilities of the firm in dealing with complex systems; and a Hansei system which requires individuals to be open to the negative feedback from colleagues, reflect on and learn from their own mistakes. All these practices resonate with the philosophy of Kaizen (continuous improvement) in Japanese companies, and emphasise employees' active participation in improvement and problem solving. The developers are fully committed to this and in this way the lead firms' requirements are transferred into the supplier.

\section{Managing the gap between lead firm expectations and supplier firm realities}

Given the extensive training offered to the developers and their deep involvement in Japanese companies, high-quality and customized design has always been the competitive advantage of Software-Co. Developers are often considered as a group of people who are experienced, hard-working, reliable, highly committed and capable of accomplishing predictable results for their Japanese lead firm. Because of all this experience and the way in which the reward and career system is organized to replicate the Japanese lifetime model, the software 
developers are effectively carriers of and transmission mechanisms for the procedures, practices and cultures of the Japanese lead firm into the Chinese setting. Lead firm practices penetrate deeply amongst this group in spite of an unfavourable institutional context where the labour market for this type of employee is extremely fluid and both employers and employees act opportunistically. They therefore have to be insulated from the potentially disturbing effects of this local institutional contexts by the forms of financial, organizational and cultural lock-ins described earlier. Compared to the ceremonial adoption of Japanese practices evident in Data-Co, Software-Co has shown a normative commitment to Japanese practices. One manager made an analogy that "the firm aims to be "a Japanized Chinese" instead of a "Chinese in Kimino"'(S-T32).

However, such a high level of socialization only occurs among developers. Programmers are excluded from the OJT programmes in Japan, nor are they involved in any of Japanese practices mentioned above. Indeed, programmers' work is usually experienced to be repetitive, monotonous and formalised. Their work involves converting the design into lines of code and conducting tests, strictly following a minutely prescribed guide book of long lists of items which need to be tested with detailed instruction on how to test each item. For each item, programmers need to tick the box to confirm that it has been tested and also fill in the expected and actual results.

Overall, Software-Co develops a work system that allows for the intense socialization of the software developers into the Japanese language and Japanese practices. This gives the Japanese firm confidence in the quality of the work it receives and serves to increase interdependence between Software-Co and the NRI. Meanwhile, Software-Co limits such socialization to developers to sustain its economic viability. Such a strategy is made possible by the ready availability of programmers in the local labour market. The contrasting treatment of developers and programmers, however, has nurtured significant grievances 
among the programmers. This resulted in some programmers' attempts to impede developers' work in teams by refusing to take overtime work even when the teams had very tight deadlines, or by being deliberately unhelpful in teamwork. In sum, Software-Co has developed a work and employment system that is bifurcated between developers and programmers. Software developers, as the core employees, are socialized into Japanese methods and processes which allows them to actively manage the relationship with the client. They are highly knowledgeable about how the client works and what the client's expectations are. These developers are a highly valuable resource in keeping the business in the supply chain and they are held tight by the company through its seniority rewards system and its penalties for early departure. The elite status of the group also reinforces these rewards and makes them dominant within the company. However, this is a highly costly strategy and only works because it is combined with the employment of relatively low skilled programmers paid relatively low wages and offered no training. Once again it is the ability to manage the demands of the overseas client with its own expectations, in the context of the local labour markets that enables the supplier firm to meet the product market demands of its client.

\section{Discussion and conclusions}

In this section, we firstly compare our cases and how managers use institutional resources to meet the expectations of lead firms in the global supply chains. We then consider the broader theoretical implications of our results for the study of global supply chains and social relations at work.

In relation to our cases, we deal firstly with the similarities. In this respect the most important similarity for our argument is that in order to participate in global supply chains in a way which both meets the requirements of clients and enables the supplier to survive, managers of supplier firms have to utilize the institutional resources available to them in their 
home context. This is a task of varying difficulty. Where the lead firm has high expectations and is closely involved on an ongoing basis with the supplier firm, this may require the supplier to find ways of avoiding institutional constraints. This was the case with SoftwareCo and its relationship to NRI. It had to find ways of overcoming the fact that software developers were highly desirable on the Shanghai labour market; the temptation was for the developers to be opportunistic and use their labour market mobility to maximize their rewards. Software-Co and NRI's business model was however built on the basis of deep and long-lasting relationships to generate firm-specific knowledge and skills. Software-Co therefore had to build a work system that insulated its software developers from the opportunism facilitated in the Shanghai institutional context and instead encouraged longterm commitment. This was done by creating a specific reward structure and elite culture that tied software developers into the firm in spite of the local institutional context and allowed the supplier to meet the lead firm's expectations of long-term intense relationships of cooperation and development. However, this was only possible because it was complemented by a workforce of programmers who reflected much more clearly the institutional context, i.e. they were part of a larger labour pool of semi-skilled IT programmers who were paid local market rates for jobs that were relatively standardised. Thus Software-Co took advantage of the Chinese institutional context for this group (and in this way kept their costs down) whilst for the developers they built a different system effectively placing this group behind a barrier separated from the local institutional context. This reflects a combination of 'maximal adaptation' in which the supplier firm incorporates wholesale the expectations of the lead firms but insulates the work group (e.g. the software developers) from the effects of the local institutional context and 'minimal adaptation' in which the supplier firm uses the resources available in its institutional context (e.g. the software programmers). 
In Data-Co, the Japanese clients had certain expectations but they were more limited than NRI and they did not invest so much in developing a relationship with Data-Co. DataCo itself had to show that it understood these expectations and it would seek to meet them. However, in practice, this adaptation was mainly ceremonial, most pertinent at the time of client visits but not enforced strongly most of the time. As we have shown, Data-Co in no way runs a Japanese system; instead it is driven very much by its local institutional context where key issues concern a highly flexible supply of medium level skilled workers. Managing this in a way that enables the firm to meet the Japanese company's output targets involves combining a variety of methods, few of which would be considered Japanese. Indeed, they can only use these methods because of the institutional context of Dalian where there is a large supply of such employees due to local government policies for training developed over the last two decades. This suggests a form of 'ceremonial adaptation' in which the supplier firm makes some adaptation to the lead firm's expectations but buffers its actual work practices which are based on the resources in the institutional context, from deeper changes. Because the lead firm is mainly interested in output numbers and price, it is not focused in detail on how the supplier reaches these results, though it is concerned to see at least some ceremonial conformity to Japanese standards.

In both cases, managers of the supplier firms are aiming at controlling the workplace not just for functional reasons but also as part of their strategy for maintaining their relationship with Japanese clients. Thus both firms studied are keen to impress their clients when they are on site with them in Japan or when clients visit the Chinese locations that they are aware of the high standards required of them. In Data-Co, there is an element of 'performance' in this as they know that their clients are more concerned with checking paperwork and procedures than actually observing and monitoring in detail workplace practices. In contrast, in Software-Co, the elite group of software developers are thoroughly 
socialized into the Japanese way of working by their three years training on site in Japan. Therefore, the overall ethos of the company is to draw on Japanese work practices and procedures and at least for this group, a high level of normative commitment to Japanese practices is present. Nevertheless, there is a common 'dominance' effect (Smith \& Meiksins 1995) at work in both cases in that the managers in the Chinese suppliers see Japan as the more advanced country in terms of management techniques such as quality improvement, reliability etc., and therefore do not resist the imposition of Japanese standards, even if, in the case of Data-Co, there is some 'ceremonial' conformity. Rather they are happy to learn about these practices and discourses, in the case of Data-Co as it improves their business position vis-à-vis other potential Japanese business (they can 'talk the talk' of Japanese standards even if they do not in practice 'walk the talk') and in the case of Software-Co because it reinforces their elite status and distinctiveness from other Chinese competitors.

In broader terms, our discussion draws attention to the importance of institutions to understanding how global supply chains impact on social relations at work. The influence of the local Chinese institutional context was clearly important in our case. Although there are commonalities in terms of how national policies on labour representation (Friedman and Lee 2010), and on skill upgrading through universities and technical schools and its consequences for labour market supply are impacting on them, there are some significant regional differences between Dalian and Shanghai (see, for example, the discussions on regions in Breznitz \& Murphree 2011 and on China as a form of 'variegated capitalism' in Peck \& Zhang 2016). Local labour markets in China can vary greatly not just across low growth compared to high growth areas but also in terms of different high growth areas. Thus some areas in China, e.g. Shanghai and Beijing amongst others, are growing on the basis of the development of high technology manufacturing and service firms where employees are increasingly qualified up to postgraduate level through education at top ranked Chinese and 
overseas universities. Supply of high level skilled workers is barely keeping pace, resulting in a strong labour market position for such employees, encouraging job hopping and opportunism. Other areas such as Dalian are characterised by an upgrading of intermediate skills from technical schools supplemented by local universities and are growing in middle range industries such as BPO. Here labour market demand can still fluctuate but with supply growing, the situation for firms and employees is more fluid; opportunities can arise but not as many or as lucrative as in Shanghai. By comparison other areas such as around Shenzen remain dominated by low grade manufacturing and relatively low skilled employees often housed in dormitories and employed on short term contracts with a lack of residency rights. As the 'variegated capitalism' model suggests, therefore, certainly in the case of China local institutional contexts need to be taken into account as much as macro-level institutions such as the lack of independent trade unions.

Institutions also come into play in terms of lead firms. Japanese lead firms come from an institutional context that in spite of some limited changes, still remains relatively homogeneous in terms of its work and employment system where long-term employment, the development of firm-specific knowledge and skills, high attention to quality and product improvement formalized in various systems such as kaizen, $5 S$, hansei remain central (Deeg \& Jackson 2006; Aoki et al. 2012). The Japanese system is also characterised by high levels of interactions and cooperation between connected networks of firms and this remains an important part of how they also develop offshore outsourcing arrangements though as our study shows this can be variable in its intensity.

Global supply chains involve bridging these gaps between institutional contexts. For managers in supplier firms, how do they use their institutional resources to meet the expectations of the lead firm (c.f. Lakhani et al. 2013)? Where these expectations are predominantly gauged by output, e.g. measurable on price and quality criteria, lead firms may 
take little further interest in the supplier and the main influence on work practice will be how managers make use of local institutional resources. Where, however, the lead firm is more committed to its own practices and processes, the supplier firm may have to respond by building a form of barrier between its own work system and that of the surrounding institutional context -as in the case of the software developers in Software-Co. It may have to find ways to reconstitute the practices of the lead firm in a different institutional context $-\mathrm{a}$ difficult undertaking. Under what conditions this can be done and for how long it can continue is an interesting area for further investigation. Alternatively, managers in the supplier firm may find they are able to adapt in a predominantly ceremonial form to the requirements of the lead firm, taking on some of the outward appearance of their practices whilst mainly running things in accordance with the resources provided by the local institutional context. How sustainable this strategy is would also be worth further investigation. Under what conditions might the lead firm pierce this 'veil' and with what consequences? Does the management in the supplier firm have free rein to develop these strategies?

In conclusion, our argument is that social relations at work in global supply chains are fundamentally affected by the bridging of institutional contexts. We support the argument in authors such as Lakhani et al. (2013) and Coe and Yeung (2015), that managers in supplier firms have to strategize as to how they adapt their local institutional resources to the requirements of lead firms. In our empirical study, however, we have gone further than these previous discussions and uncovered three main ways in which this was happening - minimal adaptation with a focus on outputs, maximal adaptation by shielding the work group from the institutional context and incorporating wholesale the lead firms' requirements, ceremonial adaptation where the presentation to lead firm clients emphasizes conformity to their requirements but in reality, practices are primarily shaped by the local institutional context. 
Research on social relations at work in global supply chains could investigate these and other potential forms of adaptation further in a wider variety of sectors, supply chains and institutional contexts. For example, none of our cases really cover examples of what might be labelled a 'learning adaptation', as described in the studies of IKEA's relationships with its suppliers in China (Ivarsson \& Alvstam 2011) or in some of the cases in Locke (2013). What combination of institutional conditions, lead firm requirements, global supply chains and strategies pursued by supplier firms leads to upgrading of the supplier firm through learning from the buyer? Related to this, our framework could be applied to understanding how codes of conduct operate in supply chains, particularly at the lower end of the value chain; do supplier firms engage in minimal adaptation, ceremonial adaptation or wholesale adaptation of these codes? Our research suggests this depends on the degree of pressure exercised by the lead firm and other outside stakeholders, the resources which supplier firms can draw on in their local institutional context and the degree to which the supplier firm can engage in (and get away with) impression management and ceremonial adaptation. By drawing together institutional analysis and the study of global supply chains, a range of possibilities for further research opens up on how managers in supplier firms organize their work systems under the dual pressures of institutional constraints and lead firm requirements. Such research can avoid deterministic explanations of social relations at work within global supply chains and instead can give due recognition to how actors (both managers and employees) respond to and reshape their work practices in the light of these pressures. Our argument therefore also reinforces recent calls for more agent centred approaches to supply chains (Coe \& Yeung 2015; Bair and Werner 2015; Lakhani et al. 2013).

\section{References}

Aoki, K., Delbridge, R. \& Endo, T., 2012. “Japanese Human Resource Management” in Postbubble Japan. The International Journal of Human Resource Management, (May 2013), pp.1-22.

Appelbaum, R.P., 2008. Giant transnational contractors in East Asia: emergent trends in global supply chains. Competition \& Change, 12(1), pp.69-87. 
Bair, J. \& Werner, M., 2015. Global production and uneven development: when bringing labour in isn't enough. In K. Newsome et al., eds. Putting Labour in Its Place: Labour Process Analysis and Global Value Chains. Basingstoke: Palgrave, pp. 119-134.

Barrientos, S. \& Kritzinger, A., 2004. Squaring the circle: global production and the informalization of work in South African Fruit Exports. Journal of International Development, 16(1), pp.81-92.

Berger, S., 2005. How we compete: what companies around the world are doing to make it in today's global economy, Crown Business.

Breznitz, D. \& Murphree, M., 2011. Run of the red queen: government, innovation, globalization, and eonomic growth in China, New Haven: Yale University Press.

Chan, J., Pun, N. \& Selden, M., 2013. The politics of global production: Apple, Foxconn and China's new working class. New Technology, Work and Employment, 28(2), pp.100115.

Coe, N. \& Yeung, H.W., 2015. Global production networks: theorising economic development in an interconnected world, Oxford: Oxford University Press.

Coe, N.M., Dicken, P. \& Hess, M., 2008. Global production networks : realizing the potential. Journal of Economic Geography, 8(February), pp.271-295.

Corbin, J. \& Strauss, A., 2008. Basics of qualitative research: techniques for developing grounded theory, Thousand Oaks, CA: Sage Publications.

Cumbers, A., Nativel, C. \& Routledge, P., 2008. Labour agency and union positionalities in global production networks. In Journal of Economic Geography. pp. 369-387.

Deeg, R. \& Jackson, G., 2006. Towards a more dynamic theory of capitalist variety. SocioEconomic Review, 5(1), pp.149-179. Available at: http://ser.oxfordjournals.org/cgi/doi/10.1093/ser/mwl021 [Accessed March 19, 2014].

Eun, J.-H., Lee, K. \& Wu, G., 2006. Explaining the "university-run enterprises" in China: a theoretical framework for university-industry relationship in developing countries and its application to China. Research Policy, 35(9), pp.1329-1346.

Feuerstein, P., 2013. Patterns of work reorganization in the course of the IT Industry's internationalization. Competition \& Change, 17(1), pp.24-40.

Flecker, J. \& Meil, P., 2010. Organisational restructuring and emerging service value chains: implications for work and employment. Work, Employment \& Society, 24(4), pp.680698.

Frenkel, S.J., 2001. Globalization, Athletic Footwear Commodity Chains and Employment Relations in China. Organization Studies, 22(4), pp.531-562.

Friedman, E.D. \& Lee, C.K., 2010. Remaking the world of Chinese labour : a 30-year retrospective. British Journal of Industrial Relations, 48(3), pp.507-533.

Friedman, T.L., 2005. The world is flat: a brief history of the twenty-first century, New York: Farrar, Straus and Giroux (FSG).

Gapp, R., Fisher, R. \& Kobayashi, K., 2008. Implementing 5S within a Japanese context: an integrated management system. Management Decision, 46(4), pp.565-579.

Gereffi, G., 1996. Global Commodity Chains: New Forms of Coordination and Control Among Nations and Firms in International Industries. Competition \& Change, 1(4), pp.427-439.

Gereffi, G., Humphrey, J. \& Sturgeon, T., 2005. The governance of global value chains. Review of International Political Economy, 12(1), pp.78-104.

Haidinger, B. \& Flecker, J., 2015. Positioning labour in service value chains and networks: the case of parcel delivery. In K. Newsome et al., eds. Putting Labour in Its Place: Labour Process Analysis and Global Value Chains. Palgrave Macmillan, pp. 64-82.

Hall, P.A. \& Soskice, D., 2001. Varieties of Capitalism: the institutional foundations of comparative advantage, Oxford: Oxford University Press.

Hammer, N. \& Riisgaard, L., 2015. Labour and segmentation in value chains. In K. Newsome et al., eds. Putting Labour in Its Place: Labour Process Analysis and Global Value Chains. Basingstoke: Palgrave Macmillan.

Hammersley, M. \& Atkinson, P., 1995. Ethnography: principles in practice 2nd editio., London and New York: Routledge.

Henderson, J. et al., 2002. Global production networks and the analysis of economic development. Review of International Political Economy, 9(3), pp.436-464.

Hill, S. \& Wilkinson, A., 1995. In search of TQM. Employee Relations, 17(3), pp.9-26. 
Howcroft, D. \& Taylor, P., 2013. Editorial: "Harvesting a bitter fruit"-work and labour in China's consumer electronics supply chain. New Technology, Work and Employment, 28(2), pp.83-83.

Ivarsson, I. \& Alvstam, C.., 2011. Upgrading in global value chains: a case study of technology learning among IKEA-suppliers in China and Southeast Asia. Journal of Economic Geography, 11, pp.731-752.

KPMG, 2013. Inside the Dragon 2013: Outsourcing Destinations in China,

Kristensen, P.H. \& Morgan, G., 2012. From Institutional Change to Experimentalist Institutions. Industrial Relations, 51(SUPPL. 1), pp.413-437.

Kuruvilla, S., Lee, C.K. \& Gallagher, M.E., 2011. From iron rice bowl to informalization: Markets, workers and the state in a changing China, Cornell University Press.

Lakhani, T., Kuruvilla, S. \& Avgar, A., 2013. From the firm to the network : global value chains and employment relations theory. British Journal of industrial relationselations, 31(3), pp.440-472.

Lane, C., 2008. National capitalisms and global production networks : an analysis of their interaction in two global industries 1. Socio-Economic Review, (6), pp.227-260.

Lane, C. \& Probert, J., 2009. National Capitalisms: Global Production Networks: Fashioning the value chain in the UK, US and Germany, Oxford University Press.

Liker, J., 2004. The Toyota Way: 14 Management Principles from the World's Greatest Manufacturer, McGraw-Hill.

Locke, R., 2013. The Promise and Limites of Private Power: Promoting Labour Standard in a Global Economy, New York: Cambridge University Press.

Morris, J., Wilkinson, B. \& Gamble, J., 2009. Strategic international human resource management or the "bottom line"? The cases of electronics and garments commodity chains in China. The International Journal of Human Resource Management, 20(2), pp.348-70.

Newsome, K. et al., 2015. Putting labour in its place: Labour process analysis and global value chains, Basingstoke: Palgrave.

Ngai, P. \& Smith, C., 2007. Putting Transnational Labour Process in Its Place: the Dormitory Labour Regime in Post-socialist China. Work, Employment \& Society, 21(1), pp.27-45.

Raworth, K. \& Kidder, T., 2009. Mimicking "lean" in global value chains: it's the workers who get leaned on. In J. Bair, ed. Frontiers of Commodity Chain Research. Yale University Press.

Sako, M., 1992. Prices, quality and trust., Cambridge: Cambridge University Press.

Sako, M., 2006. Shifting boundaries of the firm: Japanese company - Japanese labour, Oxford: Oxford University Press.

Simeon, R., 2010. Evaluating the strategic implications of Japanese IT offshore outsourcing In China and India. International Journal of Management and Information Systems, 14(3), pp.25-36.

Smith, C., 2006. The Double Indeterminacy of Labour Power: Labour Effort and Labour Mobility. Work, Employment \& Society, 20(2), pp.389-402.

Smith, C. \& Chan, J., 2015. Working for two bosses: student interns as constrained labour in China. Human Relations, 68(2), pp.305-326.

Smith, C. \& Meiksins, P., 1995. System, society and dominance effects in cross-national organisational analysis. Work Employment Society, 9, pp.241-267.

Smith, M. et al., 2002. Networks of value, commodities and regions: reworking divisions of labour in macro-regional economies. Progress in Human Geography, 1(26), pp.41-63.

Taylor, P., 2015. Labour and the changing landscapes of the call centre. In K. Newsome et al., eds. Putting Labour in Its Place: Labour Process Analysis and Global Value Chains. Basingstoke: Palgrave.

Taylor, P. et al., 2015. Putting labour in its place: labour process analysis and global value chains. In K. Newsome et al., eds. Putting Labour in its Place: Labour Process Analysis and Global Value Chains. Basingstoke: Macmillan, pp. 1-26.

Taylor, P., 2010. The globalisation of service work: analysing the transnaitonal call centre value chain. In P. Thompson \& C. Smith, eds. Working life: renewing labour process analysis. Basingstoke: Palgrave Macmillan.

Watson, T., 2011. Ethnography, reality, and truth: the vital need for studies of "how things work" in organizations and management. Journal of Management Studies, 48(1), 
pp.202-217.

Whitley, R., 1996. Business Systems and Global Commodity Chains: Competing or Complementary Forms of Economic Organisation. Competition and Change, 1(4), pp.411-4225.

Whitley, R., 2007. Business systems and organizational capabilities: the institutional structuring of competitive competences, Oxford: Oxford University Press.

Wilkinson, B. et al., 2001. The new international division of labour in Asian electronics: work organization and human resources in Japan and Malaysia. Journal of Management Studies, 38(5), pp.675-695.

Zhang, J. \& Peck, J., 2016. Variegated Capitalism, Chinese Style: Regional Models, Multiscalar Constructions. Regional Studies, 50(1), pp.52-78. 